\title{
PENGARUH KUPON, MATURITAS, LIKUDITAS DAN SUKU BUNGA TERHADAP YIELD OBLIGASI KORPORASI
}

\author{
Kadek Ary Asta Pramita Sari ${ }^{1}$ \\ Henny Rahyuda ${ }^{2}$ \\ ${ }^{1,2}$ Fakultas Ekonomi dan Bisnis Universitas Udayana, Bali, Indonesia \\ email: aryasta_pramita@yahoo.com
}

\begin{abstract}
ABSTRAK
Kinerja suatu obligasi dapat dilihat dari besaran yield yang nantinya berguna sebagai informasi dalam pengambilan keputusan investasi. Penelitian ini bertujuan untuk mengetahui bagaimana pengaruh kupon, maturitas, likuiditas dan suku bunga terhadap yield obligasi korporasi. Penelitian ini dilakukan pada seluruh perusahaan yang menerbitkan obligasi korporasi dan terdaftar di Bursa Efek Indonesia periode 2015-2017 dengan jumlah sampel penelitian sebanyak 44 obligasi dari 23 perusahaan melalui teknik sampling jenuh. Menggunakan teknik analisis data regresi linier berganda dan metode pengumpulan data yang digunakan yaitu metode observasi non partisipan dengan. Berdasarkan hasil analisis ditemukan bahwa kupon, maturitas dan suku bunga berpengaruh positif signifikan terhadap yield obligasi. Sebaliknya, likuiditas berpengaruh negatif signifikan terhadap yield obligasi. Kata kunci : kupon, maturitas, likuiditas, suku bunga dan yield obligasi
\end{abstract}

\section{ABSTRACT}

The performance of bonds reflect from bond yields that are useful as information in making investment decisions. The purpose of this study was to determine the effect of coupon, maturity, liquidity and interest rate of the corporate bond yields This research was conducted on all companies that issue corporate bonds and are listed in Indonesian Stock Exchange on 2015-2017 periods. with a total sample of 44 bonds from 23 companies through non purposive sampling technique. Data analysis technique used multiple linear regression analysis and methods of data collection in this study using non-participant observation. Based on data analysis indicate that coupon, maturity, and interest rate partially positive and significant effect on bond yields. By contrast, liquidity partially negative and significant effect on bond yields.

Keyword : coupon, maturity, liquidity and interest rate, bond yields 


\section{PENDAHULUAN}

Investasi adalah komitmen untuk menanamkan sejumlah dana pada saat ini dengan tujuan memperoleh keuntungan di masa mendatang. Pengelolaan aset finansial erat kaitannya dengan investasi terutama sekuritas yang bisa diperdagangkan. Investor berinvestasi untuk mendapatkan keuntungan di masa yang akan datang sedangkan perusahaan dapat menggunakan dana tersebut untuk mengembangkan proyeknya (Tandelilin, 2010). Investasi jangka panjang dilakukan di pasar modal dimana pengguna pasar modal ini adalah individuindividu, organisasi laba dan non laba, maupun pemerintah. Salah satu instrumen dalam pasar modal adalah obligasi.

Obligasi merupakan surat berharga atau sertifikat yang berisi perjanjian antara perusahaan emiten sebagai peminjam dana dengan investor sebagai pemberi dana (Tandelilin, 2010). Penerbit obligasi wajib membayarkan bunga secara rutin serta melunasi pokok pinjaman saat jatuh tempo. Salah satu jenis obligasi yaitu obligasi korporasi. Obligasi korporasi adalah surat utang jangka panjang yang dikeluarkan oleh perusahaan (Hartono, 2016).

Obligasi korporasi memiliki tingkat risiko gagal bayar, berbeda dengan obligasi pemerintah yang disebut juga dengan obligasi bebas risiko karena pemerintah dapat mencetak uang atau menaikkan pajak guna melunasi pembayaran obligasi pada saat jatuh tempo. Tingkat risiko gagal bayar bergantung pada ketentuan dan karakteristik perusahaan penerbit sehingga tingkat risiko gagal bayarnya berbeda-beda (Brigham \& Houston, 2010). Beberapa hal yang menyebabkan investor lebih tertarik investasi obligasi dibandingkan saham. Pertama, risiko kerugian yang akan diterima investor rendah dikarenakan pendapatan yang diberikan oleh obligasi cenderung bersifat tetap. Kedua, obligasi lebih aman karena dibandingkan dengan pemegang saham, investor obligasi akan lebih diutamakan dalam pengembalian dananya apabila suatu perusahaan mengalami kebangkrutan. Hal ini dikarenakan telah ada kontrak perjanjian untuk melunasinya.

Berdasarkan data statistik Pasar Modal Indonesia terjadi peningkatan penerbitan obligasi korporasi di Indonesia yang ditunjukkan dalam gambar 1 .

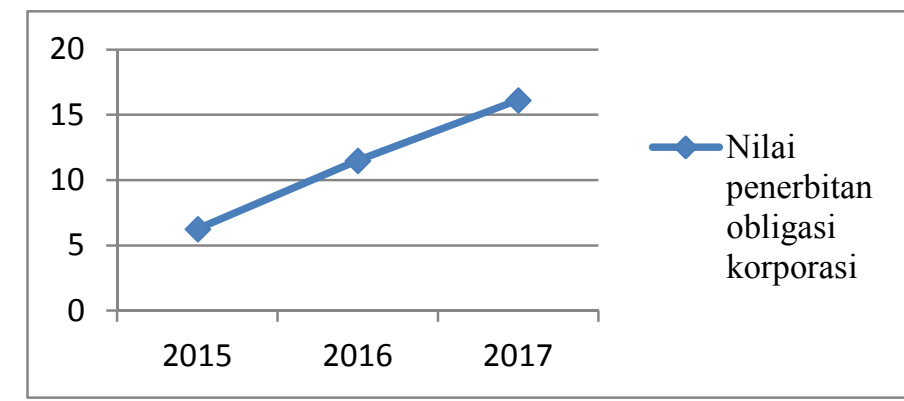

Gambar 1: Nilai penerbitan obligasi korporasi (dalam puluh triliun)

Sumber : www.cnnindonesia.com, data diolah 2018

Nilai penerbitan baru obligasi korporasi sesuai dengan gambar 1 menunjukkan bahwa sepanjang 2017 tercatat mencapai Rp 161,36 triliun atau 
meningkat hingga 40,23 persen dari posisi akhir 2016 sebesar Rp 115,06 triliun dan juga jauh lebih tinggi jika dibandingkan dengan akhir tahun 2015 sebesar Rp 62,75 triliun. Obligasi korporasi dipilih sebagai obyek penelitian dikarenakan nilai penerbitan obligasi yang terus meningkat pada tahun 2015-2017 menunjukkan obligasi korporasi semakin diminati dan semakin banyak diperdagangkan, selain itu kenaikan harga obligasi korporasi cenderung lebih stabil dibandingkan obligasi pemerintah dan obligasi korporasi memiliki eksposur risiko yang lebih tinggi terhadap kupon, maturitas, likuiditas dan suku bunga.

Yield obligasi merupakan ukuran pendapatan obligasi yang bersifat tidak tetap, seiring dengan perubahan kondisi perekonomian nilai yield akan mengalami perubahan baik secara mikro maupun makro. Obligasi merupakan investasi yang memiliki risiko dimana risiko tersebut akan mempengaruhi tingkat return yang diharapkan investor. Dalam menginvestasikan dana pada obligasi, yield sangat penting diperhatikan oleh investor, hal ini dikarenakan besar atau kecilnya keuntungan yang akan didapatkan oleh investor tercermin dari besaran yield obligasi (Susanti \& Permana, 2016).

Suku bunga SBI seringkali dijadikan dasar bagi penetapan yield obligasi yang diterbitkan oleh pemerintah maupun korporasi. Jika suku bunga acuan turun, yield obligasi juga ikut turun, meski terkadang penurunan itu tidak langsung terjadi dan dengan besaran yang berbeda. Rata-rata tingkat suku bunga pada tahun 2015 sebesar 7,51 persen dan pada tahun 2016 mengalami penurunan menjadi 6 persen dan tahun 2017 menjadi 4,5 persen. Yield obligasi juga ikut mengalami penurunan dimana sepanjang tahun 2015 yield menjadi 8,2 persen hingga 8 persen dan tahun 2017 memiliki rata-rata yield 7,6 persen (Iman, 2015).

Kinerja dari suatu obligasi tercermin dari besaran yield obligasi yang nantinya digunakan sebagai informasi dalam pengambilan keputusan investasi. Yield to maturity merupakan ukuran yield yang paling sering digunakan investor. Yield to maturity adalah tingkat return majemuk yang akan diterima investor jika membeli obligasi pada harga pasar saat ini dan menahan obligasi tersebut hingga jatuh tempo (Tandelilin, 2010). Diantara tanggal pembelian sampai pada tanggal jatuh temponya yield obligasi yang diperhitungkan akan sering mengalami perubahan bergantung pada kondisi pasar yaitu perubahan pada faktor makro maupun mikro. Faktor yang perlu dipertimbangkan terkait keputusan untuk membeli atau menjual suatu obligasi yaitu faktor makro antara lain inflasi, nilai tukar suku bunga, sedangkan faktor mikro terdiri dari kupon, likuiditas, maturitas, peringkat, ukuran perusahaan dan sebagainya (Handayani dan Sri Artini, 2011). Faktor makro yang digunakan dalam penelitian ini yaitu tingkat suku bunga yang seringkali digunakan investor sebagai dasar penetapan yield yang akan diperoleh sedangkan faktor mikro antara lain kupon, maturitas dan likuiditas yang merupakan karakteristik obligasi itu sendiri. Keempat variabel tersebut dipilih karena mampu secara langsung mempengaruhi fluktuasi yield obligasi.

Faktor mikro pertama yang mempengaruhi yield obligasi adalah kupon. Kupon adalah imbalan yang diperoleh pihak yang memberikan pinjaman dari pihak peminjam dana sebagai kompensasi atas kesediaan meminjamkan dananya bagi perusahaan merupakan bunga yang nilainya tetap dan dibayarkan sesuai waktu yang telah ditetapkan (Brigham \& Houston, 2010). Ketika suku bunga 
meningkat, maka nilai kupon meningkat karena kupon yang tinggi akan menarik minat investor dalam berinvestasi, yang kemudian akan direspon oleh pasar sehingga akhirnya yield obligasi juga akan meningkat. Terdapat beberapa penelitian yang melakukan kajian mengenai pengaruh kupon terhadap yield obligasi korporasi. Penelitian (Susanti \& Permana, 2016) serta (Andrew \& Wijaya, 2012) menemukan kupon berpengaruh positif signifikan terhadap yield pasar obligasi. Namun hasil berbeda didapat oleh (Che-Yahya et al., 2016) dan (Yuliani et al., 2016) menemukan kupon berpengaruh negatif signifikan terhadap yield obligasi korporasi. Lain halnya dengan penelitian (Putri dkk., 2017) menemukan tingkat bunga kupon tidak berpengaruh pada yield obligasi.

Seorang investor tentunya harus memperhatikan maturitas obligasi. Maturitas merupakan jumlah tahun sampai jatuh tempo sebuah obligasi. Penting bagi investor mengetahui umur maturitas untuk keputusan investasi. Semakin lama maturitas obligasi akan memberi efek kenaikan risiko obligasi sehingga investor akan mengisyaratkan yield yang semakin besar pula. Terdapat beberapa penelitian yang melakukan kajian mengenai pengaruh maturitas terhadap yield obligasi korporasi. Penelitian (Dhar, 2016) menyatakan bahwa maturitas berpengaruh positif terhadap yield obligasi dan (Indarsih, 2013) menemukan maturitas berpengaruh positif terhadap yield to maturity obligasi. Sama halnya ditemukan dalam penelitian (Yuliani et al., 2016), (Sari \& Abundanti, 2015), (Andrew \& Wijaya, 2012). Berbeda dengan hasil penelitian (Susanti \& Permana, 2016) serta (Purnamawati, 2013) yang menemukan bahwa maturitas berpengaruh negatif dan signifikan terhadap perubahan yield obigasi. Lain halnya dengan penelitian (Che-Yahya et al., 2016) yang menemukan bahwa tidak ada pengaruh maturitas terhadap yield.

Faktor internal ketiga yang mempengaruhi tingkat yield adalah likuiditas. Likuiditas obligasi tercermin dari jumlah frekuensi perdagangan. Obligasi yang sering diperdagangkan oleh investor dan banyak beredar di pasar obligasi adalah obligasi yang memiliki likuiditas yang tinggi. Semakin tinggi likuiditas menyebabkan harga obligasi tersebut cenderung meningkat, hal ini menyebabkan risiko dan yield menurun. Terdapat beberapa penelitian yang melakukan kajian mengenai pengaruh likuiditas terhadap yield obligasi korporasi. Penelitian (CheYahya et al., 2016) dan (Favero et al., 2007) menemukan likuiditas suatu obligasi berpengaruh negatif signifikan terhadap yield obligasi. Namun dalam penelitian (Lin et al., 2011) menemukan likuiditas berpengaruh positif terhadap perubahan yield obligasi pemerintah. Hasil berbeda didapatkan (Indarsih, 2013) dan (Putri, 2013) yang menemukan bahwa likuiditas obligasi tidak berpengaruh terhadap yield obligasi.

Selain faktor mikro, yield juga dipengaruhi oleh faktor makro. Menurut Hartono (2016:234) dan Tandelilin (2010:277) salah satu faktor makro dalam penentuan yield obligasi adalah tingkat suku bunga SBI. Saat tingkat suku bunga SBI meningkat, maka investor lebih tertarik berinvestasi deposito di bank karena lebih menguntungkan daripada obligasi, permintaan obligasi pun menurun yang menyebabkan harga obligasi menurun pula, sebagai kompensasi investor akan meningkatkan yield yang diisyaratkan. Terdapat beberapa penelitian yang melakukan kajian mengenai pengaruh tingkat suku bunga terhadap yield obligasi 
korporasi. Penelitian (Tjandrasa, 2017) dan (Pramana \& Nachrowi, 2016) menemukan suku bunga berpengaruh positif terhadap yield obligasi. Sama halnya dengan penelitian (Dhar, 2016), (Yuliani et al., 2016), (Kurniasih \& Restika, 2015), (Sihombing et al., 2014), (Muharam, 2013) dan (Indarsih, 2013).

Berdasarkan kajian empiris yang telah diuraikan, pengaruh kupon, maturitas, likuiditas dan tingkat suku bunga terhadap yield obligasi korporasi menarik untuk diteliti kembali karena masih ditemukan adanya research gap yang terjadi pada pasar obligasi mengenai pengaruh kupon, maturitas, likuiditas dan tingkat suku bunga terhadap yield obligasi.

Kupon, maturitas dan yield erat kaitannya dengan konsep durasi. Durasi merupakan jumlah tahun yang diperlukan untuk pengembalian harga pembelian suatu obligasi. Semakin besar kupon menyebabkan durasi obligasi semakin pendek. Hal ini dikarenakan semakin cepat pengembalian biaya pembelian obligasi. Durasi memiliki hubungan terbalik dengan yield, dimana semakin pendek durasi, maka semakin besar yield. Hal ini menandakan adanya hubungan positif antara kupon dan yield obligasi (Tandelilin, 2010). Hasil penelitian ini sesuai dengan penelitian (Susanti \& Permana, 2016) serta (Andrew \& Wijaya, 2012) yang menemukan kupon berpengaruh positif signifikan terhadap yield pasar obligasi. Dengan demikian dapat diajukan hipotesis sebagai berikut:

$\mathrm{H}_{1}$ : Kupon berpengaruh positif dan signifikan terhadap yield obligasi.

Obligasi berumur pendek akan menawarkan yield relatif lebih rendah dibandingkan obligasi yang umurnya panjang (Tandelilin, 2010). Teori preferensi likuiditas menyatakan semakin lama periode waktu maka ketidakpastian juga semakin tinggi. Adapun teori preferensi habitat menyatakan jika ada imbalan yang memadai, investor akan mengubah preferensi sektor maturitasnya. Dengan demikian, semakin panjang maturitas, maka risiko obligasi akan semakin tinggi sehingga sebagai kompensasi investor mengisyaratkan yield yang semakin tinggi. Dalam penelitian (Dhar, 2016), (Yuliani et al., 2016) serta (Sari \& Abundanti, 2015) menyatakan bahwa maturitas berpengaruh positif terhadap yield obligasi. Didukung pula dengan penelitian (Indarsih, 2013) serta (Andrew \& Wijaya, 2012). Berdasarkan uraian diatas maka dapat diajukan hipotesis sebagai berikut:

$\mathrm{H}_{2}$ : Maturitas berpengaruh positif dan signifikan terhadap yield obligasi.

Semakin besar frekuensi transaksi maka semakin tinggi likuiditas sehingga harga obligasi tersebut cenderung meningkat. Likuiditas yang baik menyebabkan risiko menurun sehingga yield yang disyaratkan juga menurun. Sebaliknya jika likuiditas menurun, harga obligasi akan menurun dan berdampak pada meningkatnya yield. Hal ini ditandai dengan likuiditas memiliki hubungan negatif terhadap risiko, dimana semakin tinggi likuiditas maka semakin rendah yield yang diterima. (Che-Yahya et al., 2016) dan (Tandra, 2018) menemukan likuiditas suatu obligasi berpengaruh negatif terhadap yield obligasi, begitu pula (Favero et al., 2007) menyatakan bahwa likuiditas berpengaruh negatif terhadap yield to maturity. Berdasarkan uraian diatas maka dapat diajukan hipotesis sebagai berikut:

$\mathrm{H}_{3}$ : Likuiditas berpengaruh negatif dan signifikan terhadap yield obligasi.

Saat meningkatnya suku bunga SBI, investor akan lebih tertarik investasi deposito di bank karena lebih menguntungkan daripada berinvestasi obligasi. 
Investor terdorong untuk mengubah obligasi yang dimilikinya dan menjadi deposito dengan menjualnya sehingga penawaran obligasi meningkat sedangkan permintaan obligasi menurun kemudian investor akan meminta kompensasi dengan meminta yield yang lebih tinggi (Saputra, 2014). (Sihombing et al., 2014) dan (Indarsih, 2013) menemukan bahwa suku bunga berpengaruh positif terhadap yield obligasi. Sama halnya (Tjandrasa, 2017), (Pramana \& Nachrowi, 2016), (Dhar, 2016), (Yuliani et al., 2016), (Hsing, 2015), (Kurniasih \& Restika, 2015), (Lin et al., 2011). Berdasarkan uraian diatas maka dapat diajukan hipotesis sebagai berikut:

$\mathrm{H}_{4}$ : Suku bunga berpengaruh positif dan signifikan terhadap yield obligasi.

Teori harapan, menyatakan tingkat bunga obligasi jangka panjang selama nperiode akan sama dengan nilai rata-rata bunga jangka pendek selama n-periode yang sama. Struktur tingkat bunga memperhitungkan penentuan tingkat bunga sekarang dan tingkat bunga yang akan diterima kemudian. Teori preferensi likuiditas, menyatakan bahwa tingkat bunga akan mencerminkan jumlah tingkat bunga sekarang dan tingkat bunga jangka pendek yang diharapkan ditambah dengan premi likuiditas. Semakin lama periode waktu maka ketidakpastian juga semakin tinggi, sehingga investor akan lebih menyukai investasi jangka pendek.Teori preferensi habitat, menyebutkan bahwa investor mempunyai preferensi terhadap sektor maturitas tertentu kemudian mereka akan beralih ke maturitas lain jika terdapat imbalan yang memadai.

\section{METODE PENELITIAN}

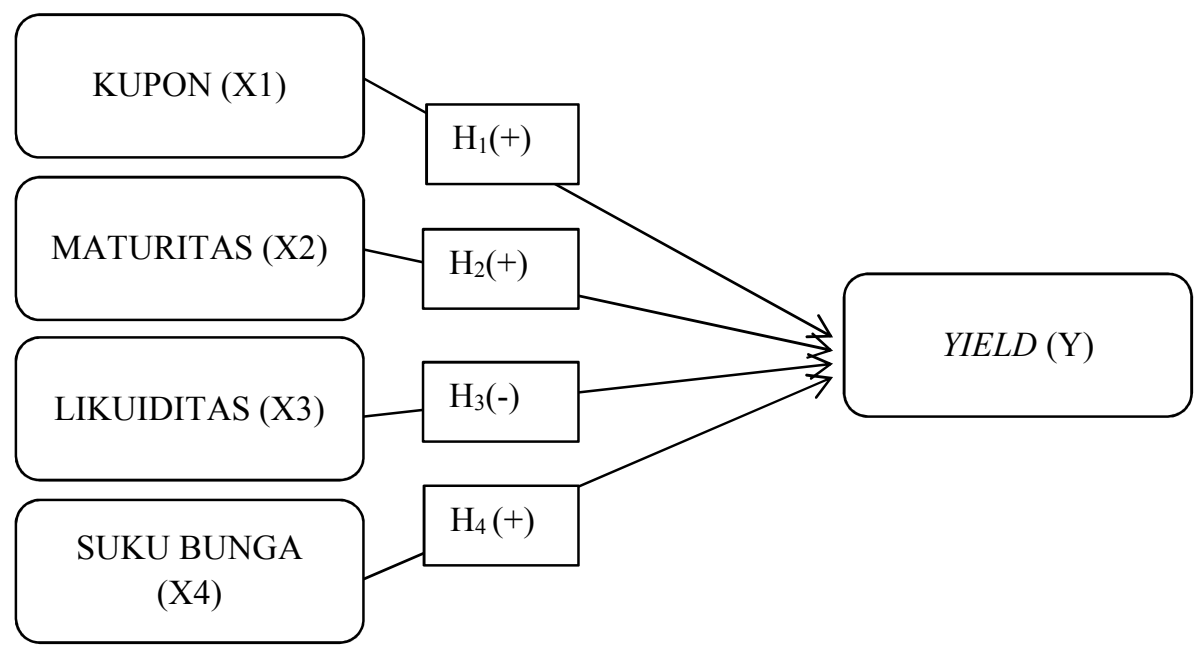

Gambar 2 : Kerangka Konseptual

Penelitian ini meggunakan desain asosiatif yaitu untuk mengetahui hubungan dua variabel atau lebih. Obyek penelitian adalah yield obligasi yang dipengaruhi oleh kupon $\left(\mathrm{X}_{1}\right)$, maturitas $\left(\mathrm{X}_{2}\right)$, likuiditas $\left(\mathrm{X}_{3}\right)$ dan suku bunga $\left(\mathrm{X}_{4}\right)$ pada perusahaan yang menerbitkan obligasi korporasi periode 2015-2017.

Berikut penjelasan mengenai pengukuran masing-masing variabel yang ada dalam penelitian ini : 
Yield merupakan ukuran pendapatan obligasi yang bersifat tidak tetap dikarenakan yield akan sangat terkait dengan tingkat return yang disyaratkan investor. Penelitian ini menggunakan yield obligasi korporasi dan dinyatakan dalam persentase (\%). Yield obligasi (Y) diukur menggunakan persamaan yield to maturity yang dapat dihitung dengan rumus (Tandelilin, 2010:260):

$$
\begin{aligned}
& \mathrm{YTM}=\frac{\mathrm{Ci}+\frac{\mathrm{Pp}-\mathrm{P}}{\mathrm{n}}}{\frac{\mathrm{Pp}+\mathrm{P}}{2}} \times 100 \% \\
& \text { Keterangan: } \\
& \text { YTM = yield to maturity (persen) } \\
& \mathrm{P} \quad=\text { harga obligasi pada saat ini }(\mathrm{t}=0)(\mathrm{Rp}) \\
& \mathrm{n} \quad=\text { jumlah tahun sampai dengan jatuh tempo obligasi (tahun) } \\
& \mathrm{C}_{\mathrm{i}} \quad=\text { pembayaran kupon untuk obligasi i setiap tahunnya } \\
& \text { (persen) } \\
& \mathrm{P}_{\mathrm{p}} \quad=\text { nilai par dari obligasi }(\mathrm{Rp})
\end{aligned}
$$

Kupon adalah bunga yang besarnya tetap dan dibayarkan oleh penerbit obligasi kepada investor sesuai waktu yang telah ditetapkan. Kupon diukur dengan menggunakan kupon yang diberikan oleh emiten obligasi saat penerbitan obligasi dan dinyatakan dalam persentase (\%).

Likuiditas adalah penilaian kemampuan perusahaan untuk menghasilkan arus kas yang cukup untuk memenuhi seluruh kewajibannya, diukur dengan menggunakan jumlah frekuensi perdagangan obligasi yang diperdagangkan di Bursa Efek Indonesia periode 2015-2017 dan dinyatakan dalam satuan kali. Maturitas diukur dengan menggunakan jumlah tahun sampai jatuh tempo obligasi yang diperdagangkan di Bursa Efek Indonesia periode 20152017. Variabel ini merupakan variabel dummy, jika obligasi memiliki umur dalam kategori short-term yaitu satu sampai lima tahun diberi kode 0 , umur jatuh tempo diatas lima sampai dua belas tahun adalah intermediate-term dengan kode 1 dan kode 2 untuk umur obligasi lebih dari dua belas tahun atau long-term (Fabozzi, 2010:3).

Suku bunga yang sering digunakan investor sebagai acuan adalah tingkat suku bunga Sertifikat Bank Indonesia (SBI). SBI adalah surat berharga yang diterbitkan oleh Bank Indonesia sebagai pengakuan utang berjangka waktu pendek dengan sistem diskonto atau bunga. Menggunakan mekanisme BI rate dan BI 7-day (reverse) repo Rate yang dipublikasikan oleh Bank Indonesia periode 2015-2017 dan dinyatakan dalam persentase.

Populasi dalam penelitian ini adalah seluruh perusahaan yang menerbitkan obligasi korporasi dan terdaftar di Bursa Efek Indonesia periode 2015-2017 yang terdiri dari 23 perusahaan dimana tiap perusahaan menerbitkan beberapa oblgasi berjumlah 44 obligasi dengan tiga tahun pengamatan sehingga diperoleh jumlah pengamatan sebesar 132. Teknik penentuan sampel yang digunakan yaitu non purposive sampling. 
Tabel 1.

Sampel penelitian

\begin{tabular}{|c|c|c|c|c|c|}
\hline No & Nama Perusahaan & Kode Obligasi & No & $\begin{array}{l}\text { Nama } \\
\text { Perusahaan }\end{array}$ & Kode Obligasi \\
\hline \multirow{4}{*}{1} & & ADMF03ACN1 & & & ISAT01CCN2 \\
\hline & Adira Dinamika & ADMF03BCN1 & & & ISAT01DCN2 \\
\hline & Multi Finance Tbk & ADMF03BCN2 & & & ISAT01DCN3 \\
\hline & & ADMF03CCN2 & & & ISAT01ECN2 \\
\hline 2 & $\begin{array}{c}\text { Sumber Alfaria } \\
\text { Trijaya Tbk }\end{array}$ & AMRT01BCN2 & 13 & $\begin{array}{l}\text { Modernland } \\
\text { Realty Tbk }\end{array}$ & MDLN01ACN1 \\
\hline 3 & $\begin{array}{l}\text { PT. Astra Sedaya } \\
\text { Finance }\end{array}$ & ASDF02BCN5 & & & MDLN01BCN1 \\
\hline 4 & $\begin{array}{l}\text { Balai Besar } \\
\text { Industri Agro }\end{array}$ & BBIA01C & 14 & $\begin{array}{l}\text { Perusahaan } \\
\text { Umum } \\
\text { Pegadaian }\end{array}$ & PPGD02CCN3 \\
\hline 5 & Bank Bukopin Tbk & BBKP02SBCN1 & 15 & $\begin{array}{l}\text { Pembangunan } \\
\text { Perumahan } \\
\text { (Persero) Tbk }\end{array}$ & PTPP01CN2 \\
\hline \multirow[t]{2}{*}{6} & $\begin{array}{l}\text { Bank Rakyat } \\
\text { Indonesia }\end{array}$ & BBRI01BCN1 & 16 & $\begin{array}{l}\text { Nippon Indosari } \\
\text { Corpindo Tbk }\end{array}$ & ROTI01CN2 \\
\hline & (Persero) Tbk & BBRI01CCN1 & 17 & $\begin{array}{l}\text { PT. Sarana } \\
\text { Multigriya } \\
\text { Finansial }\end{array}$ & SMFP03BCN1 \\
\hline \multirow[t]{2}{*}{7} & Bank Tabungan & BBTN02ACN1 & 18 & PT. Toyota Astra & TAFS01BCN2 \\
\hline & Negara (Persero) Tbk & BBTN02BCN1 & & $\begin{array}{l}\text { Financial } \\
\text { Services }\end{array}$ & TAFS01BCN3 \\
\hline 8 & Indonesia Eximbank & BEXI02BCN6 & 19 & $\begin{array}{l}\text { Tiphone Mobile } \\
\text { Indonesia Tbk }\end{array}$ & TELE01CN1 \\
\hline \multirow{3}{*}{9} & & BEXI02CCN5 & 20 & Telkom & TLKM01ACN1 \\
\hline & PT. BII Finance & BIIF01ACN1 & & Indonesia & TLKM01BCN1 \\
\hline & & BIIF01BCN1 & & (Persero) Tbk & TLKM01CCN1 \\
\hline 10 & $\begin{array}{c}\text { PT. Federal } \\
\text { International Finance }\end{array}$ & FIFA02BCN2 & & & TLKM01DCN1 \\
\hline \multirow[t]{2}{*}{11} & PT. Indomobil & IMFI02CCN1 & 21 & PT. Mandiri & TUFI02ACN1 \\
\hline & Finance & IMFI02CCN2 & & Tunas Finance & TUFI02BCN1 \\
\hline \multirow[t]{2}{*}{12} & Indosat Tbk & ISAT01ACN3 & 22 & $\begin{array}{l}\text { Wahana } \\
\text { Ottomitra }\end{array}$ & WOMF01BCN4 \\
\hline & & $\begin{array}{l}\text { ISAT01BCN2 } \\
\text { ISAT01BCN3 }\end{array}$ & 23 & $\begin{array}{l}\text { Waskita Karya } \\
\text { (Persero) Tbk }\end{array}$ & $\begin{array}{l}\text { WSKT01ACN2 } \\
\text { WSKT01BCN2 }\end{array}$ \\
\hline
\end{tabular}

Metode pengumpulan data yaitu metode observasi non partisipan dengan menggunakan jenis data yaitu data kuantitatif. Sumber data menggunakan data sekunder yang bersumber dari website BEI (www.idx.go.id), The Indonesia Capital Market Institute (TICMI) dan website Bank Indonesia (www.bi.go.org).

Pengujian hipotesis menggunakan metode regresi linier berganda dengan telebih dahulu dilakukan analisis deskriptif kemudian uji asumsi klasik. Setelah memenuhi kedua uji tersebut dilanjutkan dengan melakukan uji regresi linier berganda, uji F, uji T serta uji koefisien determinasi.

\section{HASIL DAN PEMBAHASAN}

Statistik Deskriptif 
Tabel 2.

Hasil Analisis Statistik Deskriptif

\begin{tabular}{lrrrrr}
\hline & N & Minimum & Maximum & Mean & \multicolumn{1}{c}{$\begin{array}{c}\text { Std. } \\
\text { Deviation }\end{array}$} \\
\hline N Valid & 132 & & & & \\
Kupon & 132 & 9,20 & 12,50 & 10,2022 & 0,75636 \\
Maturitas & 132 & 0 & 2 & 0,2273 & 0,51823 \\
Likuiditas & 132 & 1 & 609 & 43,1227 & 60,05959 \\
Suku Bunga & 132 & 4,56 & 7,51 & 6,0128 & 1,17402 \\
Yield & 132 & 6,93 & 12,53 & 9,1806 & 1,11676 \\
\hline Sumber: & & & &
\end{tabular}

Sumber: Data sekunder diolah, 2018

Pada Tabel 2. dapat dilihat jumlah pengamatan (N) dari penelitian ini adalah 132. Variabel yield mempunyai rentang nilai 6,93 sampai dengan 12,53 dari 132 data. Nilai terendah sebesar 6,93 oleh kode ADMF03ACN pada tahun 2017 dan nilai tertinggi sebesar 12,53 oleh kode BBKP02SBCN1 tahun 2015. Yield ratarata seluruh kode obligasi sampel adalah sebesar 9,1806 dengan simpangan baku sebesar 1,11676 .

Variabel kupon mempunyai rentang nilai 9,2 sampai dengan 12,5 dari 132 data. Nilai terendah sebesar 9,2 oleh kode BBRI01BCN1 dan BEXI02BCN6 pada tahun 2015, 2016 dan 2017. Nilai tertinggi sebesar 12,5 oleh kode MDLN01BCN1 tahun 2015, 2016 dan 2017. Kupon rata-rata seluruh kode obligasi sampel adalah sebesar 10,2022 dengan simpangan baku sebesar 0,75636.

Variabel maturitas mempunyai rentang nilai 0 sampai dengan 2 dari 132 data. Nilai terendah dengan kode 0 (short-term) sebesar 3 tahun oleh ADMF03ACN1, ADMF03BCN2, ASDF02BCN5, BBRI01BCN1, BBTN02ACN1, BEXI02BCN6, BIIF01ACN1, FIFA02BCN2, ISAT01ACN3, ISAT01BCN2, MDLN01ACN1, SMFP03BCN1, TAFS01BCN2, TAFS01BCN3, TELE01CN1, TUFI02ACN1, WOMF01BCN4, WSKT01ACN2. Nilai tertinggi dengan kode 2 (long-term) sebesar 30 tahun oleh TLKM01DCN1. Maturitas ratarata seluruh kode obligasi sampel adalah sebesar 0,2273 dengan simpangan baku sebesar 0,51823 .

Variabel likuiditas mempunyai rentang nilai 1 sampai dengan 609 dari 132 data. Nilai terendah sebesar 1 oleh kode BBTN02BCN1 dan TUFI02BCN1 pada tahun 2015. Nilai tertinggi sebesar 609 oleh kode TAFS01BCN2 tahun 2016. Likuiditas rata-rata seluruh kode obligasi sampel adalah sebesar 43,1227 dengan simpangan baku sebesar 60,05959.

Variabel suku bunga mempunyai rentang nilai 4,56 sampai dengan 7,51 dari 132 data. Nilai terendah sebesar 4,56 oleh semua kode obligasi pada tahun 2017. Nilai tertinggi sebesar 7,51 oleh semua kode obligasi pada tahun 2015. Suku bunga rata-rata seluruh kode obligasi sampel adalah sebesar 6,0128 dengan simpangan baku sebesar 1,17402.

Berdasarkan Tabel 3, nilai signifikansi sebesar 0,244 lebih besar dari 0,05 (sig. $=0,244>0,05)$. Dengan demikian variabel kupon, maturitas, likuiditas dan suku bunga berdistribusi normal. 
Tabel 3.

Uji Normalitas

\begin{tabular}{|c|c|c|}
\hline & & Unstandardized Residual \\
\hline $\mathrm{N}$ & & 132 \\
\hline \multirow[t]{2}{*}{ Normal Parameters ${ }^{\mathbf{a}, \mathbf{b}}$} & Mean &,- 0102639 \\
\hline & Std. Deviation & 0,05564131 \\
\hline Most Extreme & Absolute & 0,089 \\
\hline \multirow[t]{2}{*}{ Differences } & Positive & 0,071 \\
\hline & Negatif & $-0,089$ \\
\hline Kolmogorov-Smirnov Z & & 1,026 \\
\hline Asymp. Sig. (2-tailed) & & 0,244 \\
\hline
\end{tabular}

Sumber : Data Sekunder diolah, 2018

Tabel 4.

Uji Multikolinearitas

\begin{tabular}{lcc}
\hline Model & \multicolumn{2}{c}{ Colinearity Statistics } \\
\hline & Tolerance & VIF \\
Kupon & 0,892 & 1,121 \\
Maturitas & 0,910 & 1,099 \\
Likuiditas & 0,932 & 1,073 \\
Suku Bunga & 0,962 & 1,040 \\
\hline Sumber : Data sekunder diolah, 2018
\end{tabular}

Berdasarkan hasil yang disajikan pada Tabel 4 dapat dilihat bahwa nilai tolerance dari keempat variabel bebas yaitu kupon, maturitas, likuiditas dan suku bunga lebih dari $0,10(0,892 ; 0,910 ; 0,9320,962>0,10)$ dan nilai VIF kurang dari $10(1,121 ; 1,099 ; 1,073 ; 1,040<10)$. Maka dapat disimpulkan bahwa dalam penelitian ini tidak ada gejala multikolinearitas.

Tabel 5.

Uji Autokorelasi

\begin{tabular}{cccccc}
\hline Model & R & R Square & $\begin{array}{c}\text { Adjusted R } \\
\text { Square }\end{array}$ & $\begin{array}{c}\text { Std. Error of } \\
\text { the Estimate }\end{array}$ & $\begin{array}{c}\text { Durbin- } \\
\text { Watson }\end{array}$ \\
\hline 1 & 0,929 & 0,863 & 0,859 & 0,45876 & 1,786 \\
\hline Sumber : & Data sekunder diolah, 2018 & & &
\end{tabular}

Berdasarkan Tabel 5. nilai Durbin Watson (DW-test) sebesar 1,786 dengan $\mathrm{d}_{\mathrm{L}}$ sebesar 1,6539 dan $\mathrm{d}_{\mathrm{U}}$ 1,7786. Nilai $\mathrm{d}_{\mathrm{L}}$ dan $\mathrm{d}_{\mathrm{U}}$ diperoleh dari tabel $\mathrm{D}-\mathrm{W}$ dengan sampel sebanyak 132 dan variabel bebas sebanyak 4. Nilai Durbin Watson (DW-test) sebesar 1,786 lebih kecil dari nilai $\left(4-\mathrm{d}_{\mathrm{U}}\right)=2,2214(4-1,7786)$ dan lebih besar dari nilai $\left(\mathrm{d}_{\mathrm{L}}\right)=1,6539$ sehingga dapat disimpulkan tidak terdapat gejala autokorelasi.

Berdasarkan Tabel 6. menunjukkan bahwa nilai signifkansi masing-masing variabel yaitu kupon sebesar 0,632, maturitas sebesar 0,910, likuiditas sebesar 0,130, dan suku bunga sebesar 0,089 lebih besar dari 0,05. Berdasarkan hal tersebut, penelitian ini tidak terdapat gejala heteroskedatisitas. 
Tabel 6.

Uji Heteroskedastisitas

\begin{tabular}{|c|c|c|c|c|c|c|}
\hline \multirow{2}{*}{\multicolumn{2}{|c|}{ Model }} & \multicolumn{2}{|c|}{$\begin{array}{l}\text { Unstandardized } \\
\text { Coefficients }\end{array}$} & \multirow{2}{*}{$\begin{array}{c}\text { Standardized } \\
\text { Coefficients } \\
\text { Beta }\end{array}$} & \multirow[t]{2}{*}{$\mathbf{t}$} & \multirow[t]{2}{*}{ Sig. } \\
\hline & & B & $\begin{array}{c}\text { Std. } \\
\text { Error }\end{array}$ & & & \\
\hline \multirow[t]{5}{*}{1} & (Constant) & 0,056 & 0,115 & & 0,488 & 0,627 \\
\hline & Kupon & 0,022 & 0,046 & 0,044 & 0,480 & 0,632 \\
\hline & Maturitas & $-0,001$ & 0,006 & $-0,010$ & $-0,114$ & 0,910 \\
\hline & Likuiditas & $-0,005$ & 0,003 & $-0,138$ & $-1,526$ & 0,130 \\
\hline & Suku Bunga & $-0,028$ & 0.016 & $-0,152$ & $-1,712$ & 0,089 \\
\hline
\end{tabular}

Sumber : Data sekunder diolah, 2018

Tabel 7.

Regresi Linier Berganda

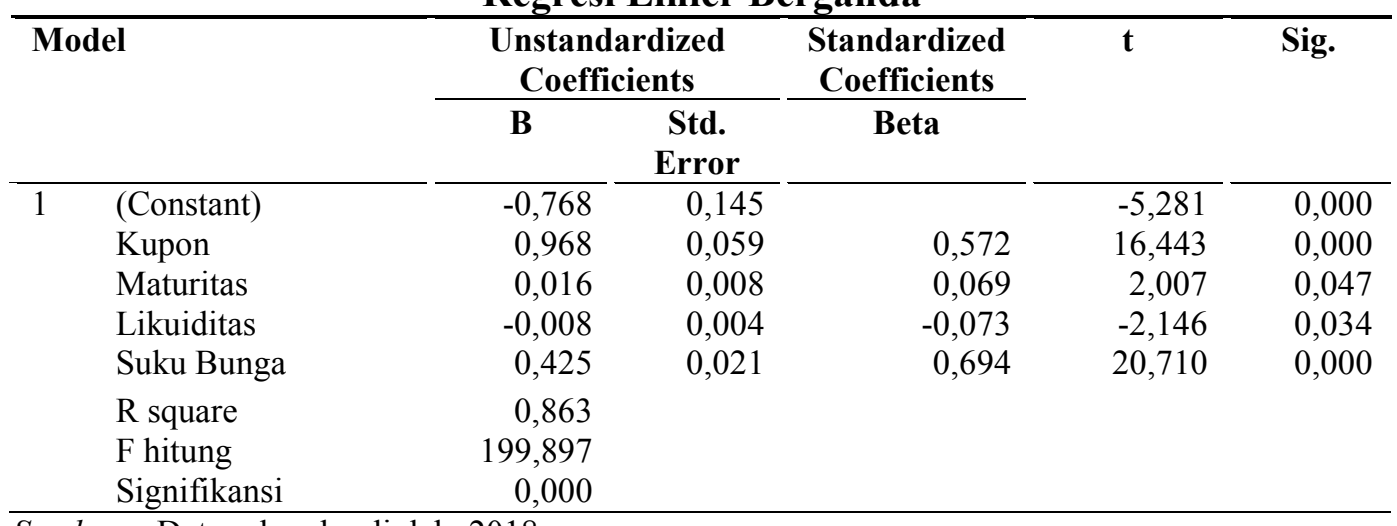

Sumber : Data sekunder diolah, 2018

Berdasarkan Tabel 7. maka dapat dibuat persamaan regresi linier berganda sebagai berikut:

$$
\mathrm{Y}=0,572 \mathrm{X}_{1}+0,069 \mathrm{X}_{2}-0,073 \mathrm{X}_{3}+0,694 \mathrm{X}_{4}+\mathrm{e}
$$

Keterangan:

$$
\begin{array}{ll}
\mathrm{Y} & =\text { yield } \text { obligasi } \\
\alpha & =\text { konstanta } \\
\mathrm{X}_{1} & =\text { kupon } \\
\mathrm{X}_{2} & =\text { likuiditas } \\
\mathrm{X}_{3} & =\text { maturitas } \\
\mathrm{X}_{4} & =\text { suku bunga } \\
\beta_{1}-\beta_{4} & =\text { koefisien regresi tiap variabel } \\
\mathrm{e} & =\text { error }
\end{array}
$$

Persamaan regresi diatas menjelaskan bagaimana arah variabel bebas dan seberapa besar pengaruhnya terhadap variabel terikat. Jika koefisien regresi bertanda negatif berarti variabel bebas memiliki pengaruh yang berlawanan arah dengan variabel terikatnya sedangkan jika koefisien regresi bertanda positif ini menandakan variabel bebas memiliki pengaruh yang searah dengan variabel 
terikatnya. Berikut dapat dijelaskan lebih rinci pengaruh masing-masing koefisien

$\beta_{1} \quad$ : 0,572 berarti apabila kupon meningkat sebesar 1 persen, maka yield obligasi akan meningkat sebesar 0,572 persen dengan syarat variabel lainnya konstan, $\beta_{2}$ : 0,069 berarti apabila maturitas meningkat sebesar 1 persen, maka yield obligasi akan meningkat sebesar 0,069 persen dengan syarat variabel lainnya konstan, $\beta_{3}$ : $-0,073$ berarti apabila likuiditas meningkat sebesar 1 persen, maka yield obligasi akan menurun sebesar 0,073 persen dengan syarat variabel lainnya konstan, $\beta_{4}: 0,694$ berarti apabila suku bunga meningkat sebesar 1 persen, maka yield obligasi akan meningkat sebesar 0,694 persen dengan syarat variabel lainnya konstan.

\begin{tabular}{|c|c|c|c|c|c|c|}
\hline \multicolumn{7}{|c|}{$\begin{array}{c}\text { Tabel } 8 . \\
\text { Uji F }\end{array}$} \\
\hline Model & & $\begin{array}{c}\text { Sum of } \\
\text { Squares }\end{array}$ & Df & $\begin{array}{c}\text { Mean } \\
\text { Square }\end{array}$ & $\mathbf{F}$ & Sig. \\
\hline \multirow[t]{3}{*}{1} & Regression & 1,683 & 4 & 0,421 & 199,897 & $0,000^{\mathrm{a}}$ \\
\hline & Residual & 0,267 & 127 & 0,002 & & \\
\hline & Total & 1,950 & 131 & & & \\
\hline
\end{tabular}

Sumber : Data sekunder diolah, 2018

Berdasarkan hasil analisis pada Tabel 8. dapat dilihat nilai probabilitas signifikansi sebesar 0,000 dibawah taraf signifikansi 0,05 . Hal ini berarti model regresi layak digunakan dalam penelitian. Terlihat pula bahwa seluruh variabel yaitu kupon $\left(\mathrm{X}_{1}\right)$, maturitas $\left(\mathrm{X}_{2}\right)$, likuiditas $\left(\mathrm{X}_{3}\right)$ dan suku bunga $\left(\mathrm{X}_{4}\right)$ secara simultan berpengaruh signifikan terhadap yield obligasi (Y).

Tabel 9.

\begin{tabular}{llrr}
\multicolumn{4}{c}{ Uji t } \\
\hline Model & \multicolumn{1}{l}{ T } & Sig. \\
& & & \\
\hline $1 \quad$ (Constant) & $-5,281$ & 0,000 \\
& Kupon & 16,443 & 0,000 \\
& Maturitas & 2,007 & 0,047 \\
& Likuiditas & $-2,146$ & 0,034 \\
& Suku Bunga & 20,710 & 0,000 \\
\hline \multicolumn{2}{l}{ Sumber : Data sekunder diolah, 2018 }
\end{tabular}

Berdasarkan analisis data pada Tabel 9, terlihat bahwa nilai koefisien regresi variabel kupon adalah sebesar 0,572 dengan taraf signifikansi sebesar 0,000. Hal ini menunjukkan bahwa taraf signifikansi variabel kupon lebih kecil dari taraf $\alpha=$ 0,05 maka dapat disimpulkan bahwa kupon berpengaruh positif dan signifikan terhadap yield obligasi korporasi. Selain itu uji t juga dapat dilakukan dengan membandingkan $t$ hitung dengan $t$ tabel dengan kriteria :

Jika $\mathrm{t}_{\text {hitung }}>\mathrm{t}_{\text {tabel}}$, maka $\mathrm{H}_{1}$ diterima atau $\mathrm{H}_{\mathrm{o}}$ ditolak Jika $\mathrm{t}_{\text {hitung }}<\mathrm{t}_{\text {tabel, }}$, maka $\mathrm{H}_{1}$ ditolak atau $\mathrm{H}_{\mathrm{o}}$ diterima 
$\mathrm{t}_{\text {tabel }}=\mathrm{t}(\alpha / 2 ; \mathrm{n}-\mathrm{k}-1)=\mathrm{t}(0,025 ; 127)=1,97882$ dan $\mathrm{t}_{\text {hitung }}=16,443$

Dengan demikian 16,443 > 1,97882, maka $\mathrm{H}_{1}$ diterima atau $\mathrm{H}_{\mathrm{o}}$ ditolak

Kupon berpengaruh positif dan signifikan terhadap yield obligasi korporasi sehingga hipotesis 1 diterima. Kupon yang tinggi akan cenderung meningkatkan minat investor untuk berinvestasi obligasi karena akan memberikan yield yang makin tinggi pula. Pengaruh kupon terhadap yield dapat dijelaskan dengan konsep durasi. Semakin besar kupon maka durasi obligasi semakin pendek. Durasi pendek menandakan semakin cepat pengembalian biaya pembelian obligasi. Jika maturitas dan pembayaran kupon obligasi dianggap tetap, maka yield akan mempunyai hubungan tidak searah dengan durasi. Sama halnya dengan kupon, yield yang besar akan mempercepat pengembalian biaya pembelian obligasi. Selain itu, kupon dan yield merupakan pendapatan dari suatu obligasi, dimana yield dihitung berdasarkan kupon yang diterima terhadap harga obligasi. Hal ini menandakan adanya hubungan positif antara kupon dan yield obligasi. Sama halnya dengan penelitian (Susanti \& Permana, 2016) serta (Andrew \& Wijaya, 2012).

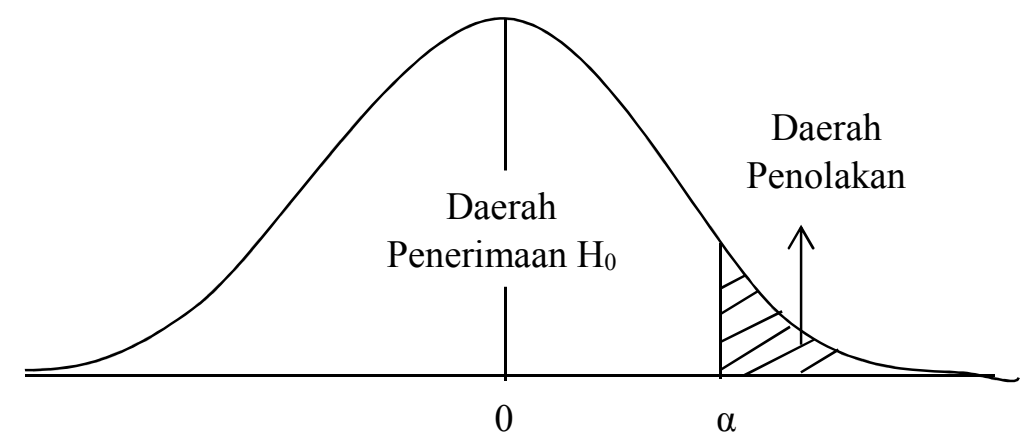

Berdasarkan Tabel 9. menunjukkan bahwa nilai koefisien regresi variabel maturitas adalah sebesar 0,069 dengan taraf signifikansi sebesar 0,047. Hasil signifikansi tersebut menunjukkan bahwa taraf signifikansi variabel maturitas lebih kecil dari taraf $\alpha=0,05$ maka dapat disimpulkan bahwa maturitas berpengaruh positif dan signifikan terhadap yield obligasi korporasi. Selain itu uji $t$ juga dapat dilakukan dengan membandingkan $t_{\text {hitung dengan } t} t_{\text {tabel }}$ dengan kriteria

Jika $\mathrm{t}_{\text {hitung }}>\mathrm{t}_{\text {tabel, }}$ maka $\mathrm{H}_{1}$ diterima atau $\mathrm{H}_{\mathrm{o}}$ ditolak

Jika $\mathrm{t}_{\text {hitung }}<\mathrm{t}_{\text {tabel, }}$, maka $\mathrm{H}_{1}$ ditolak atau $\mathrm{H}_{\mathrm{o}}$ diterima

$\mathrm{t}_{\text {tabel }}=\mathrm{t}(\alpha / 2 ; \mathrm{n}-\mathrm{k}-1)=\mathrm{t}(0,025 ; 127)=1,97882$ dan $\mathrm{t}_{\text {hitung }}=2,007$

Dengan demikian 2,007 >1,97882, maka $\mathrm{H}_{1}$ diterima atau $\mathrm{H}_{\mathrm{o}}$ ditolak

Maturitas berpengaruh positif dan signifikan terhadap yield obligasi korporasi sehingga hipotesis 2 diterima. Berdasarkan teori preferensi likuiditas yang menyatakan semakin lama periode waktu maka ketidakpastian juga semakin tinggi. Tingkat ketidakpastian yang semakin tinggi menyebabkan meningkatnya risiko yang diterima investor. Adapun teori preferensi habitat menyatakan investor mau mengubah preferensi sektor maturitasnya jika ada imbalan yang memadai. Dengan demikian, semakin panjang maturitas, maka risiko obligasi akan semakin tinggi sehingga investor akan mengisyaratkan yield yang semakin besar sebagai bentuk kompensasi. Hal ini sesuai dengan penelitian (Dhar, 2016), (Yuliani et al., 2016) serta (Sari \& Abundanti, 2015). 


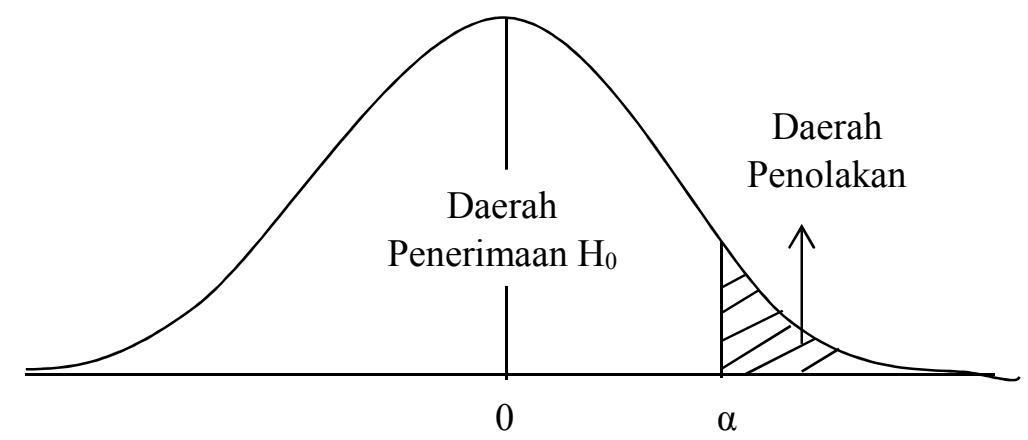

Berdasarkan analisis pada Tabel 9, nilai koefisien regresi variabel likuiditas adalah sebesar - 0,073 dengan taraf signifikansi sebesar 0,034. Hasil signifikansi tersebut menunjukkan bahwa taraf signifikansi likuiditas lebih kecil dari taraf $\alpha=$ 0,05 maka dapat disimpulkan bahwa likuiditas berpengaruh negatif dan signifikan terhadap yield obligasi korporasi. Selain itu uji t juga dapat dilakukan dengan membandingkan $t$ hitung dengan $t$ tabel dengan kriteria

Jika $\mathrm{t}_{\text {hitung }}<\mathrm{t}_{\text {tabel, }}$, maka $\mathrm{H}_{1}$ diterima atau $\mathrm{H}_{\mathrm{o}}$ ditolak

Jika $\mathrm{t}_{\text {hitung }}>\mathrm{t}_{\text {tabel, }}$, maka $\mathrm{H}_{1}$ ditolak atau $\mathrm{H}_{\mathrm{o}}$ diterima

$\mathrm{t}_{\text {tabel }}=\mathrm{t}(\alpha / 2 ; \mathrm{n}-\mathrm{k}-1)=\mathrm{t}(0,025 ; 127)=1,97882$ dan $\mathrm{t}_{\text {hitung }}=-2,146$

Dengan demikian $-2,146<1,97882$, maka $\mathrm{H}_{1}$ diterima atau $\mathrm{H}_{\mathrm{o}}$ ditolak

Likuiditas berpengaruh negatif dan signifikan terhadap yield obligasi korporasi sehingga hipotesis 3 diterima. Semakin besar jumlah frekuensi transaksi maka semakin tinggi likuiditas sehingga harga obligasi tersebut cenderung meningkat. Likuiditas yang baik menyebabkan risiko menurun sehingga yield yang disyaratkan juga menurun. Sebaliknya jika likuiditas menurun, harga obligasi akan menurun dan berdampak pada meningkatnya yield. Hal ini ditandai dengan likuiditas memiliki hubungan negatif terhadap risiko, bahwa semakin tinggi likuiditas maka yield yang diterima akan semakin rendah. Hasil penelitian ini sejalan dengan penelitian (Che-Yahya et al., 2016), (Tandra, 2018) dan (Favero et al., 2007).

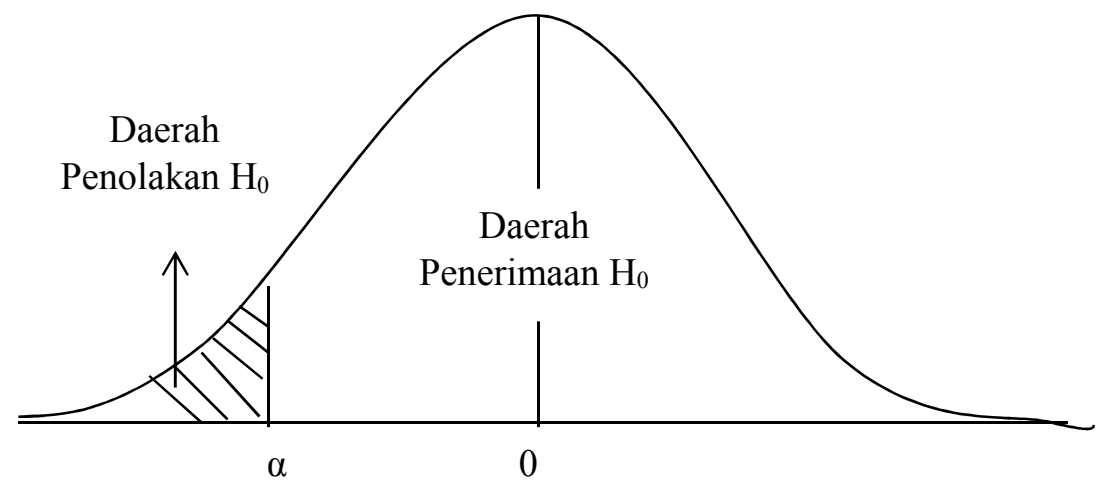

Berdasarkan Tabel 9, nilai koefisien regresi variabel suku bunga sebesar 0,694 dengan taraf signifikansi sebesar 0,000 maka taraf signifikansi variabel suku bunga lebih kecil dari taraf $\alpha=0,05$ sehingga dapat disimpulkan bahwa suku 
bunga berpengaruh positif dan signifikan terhadap yield obligasi korporasi. Selain itu uji $t$ juga dapat dilakukan dengan membandingkan $t$ hitung dengan $t$ tabel dengan kriteria :

Jika $\mathrm{t}_{\text {hitung }}>\mathrm{t}_{\text {tabel, }}$, maka $\mathrm{H}_{1}$ diterima atau $\mathrm{H}_{\mathrm{o}}$ ditolak

Jika $\mathrm{t}_{\text {hitung }}<\mathrm{t}_{\text {tabel}}$, maka $\mathrm{H}_{1}$ ditolak atau $\mathrm{H}_{\mathrm{o}}$ diterima

$\mathrm{t}_{\text {tabel }}=\mathrm{t}(\alpha / 2 ; \mathrm{n}-\mathrm{k}-1)=\mathrm{t}(0,025 ; 127)=1,97882$ dan $\mathrm{t}_{\text {hitung }}=20,710$

Dengan demikian 20,710 >1,97882, maka $\mathrm{H}_{1}$ diterima atau $\mathrm{H}_{\mathrm{o}}$ ditolak

Suku bunga berpengaruh positif signifikan terhadap yield obligasi korporasi sehingga hipotesis 4 diterima. Investor lebih menyukai investasi deposito di bank ketika tingkat suku bunga meningkat karena lebih menguntungkan dibandingkan obligasi. Sehingga pemegang obligasi akan terdorong untuk mengubah obligasi yang dimiliki menjadi deposito dengan cara menjualnya. Hal ini mengakibatkan permintaan obligasi akan lebih kecil dari penawaran. Investor harus mempertimbangkan besarnya tingkat bunga pasar karena akan berpengaruh terhadap yield obligasi. Apabila suku bunga mengalami peningkatan, investor akan meminta kompensasi dengan meminta yield yang lebih tinggi, hal ini dikarenakan kupon yang bersifat tetap (Saputra, 2014). Hasil penelitian ini didukung oleh hasil penelitian (Tjandrasa, 2017), (Pramana \& Nachrowi, 2016), (Sihombing et al., 2014) serta (Indarsih, 2013).

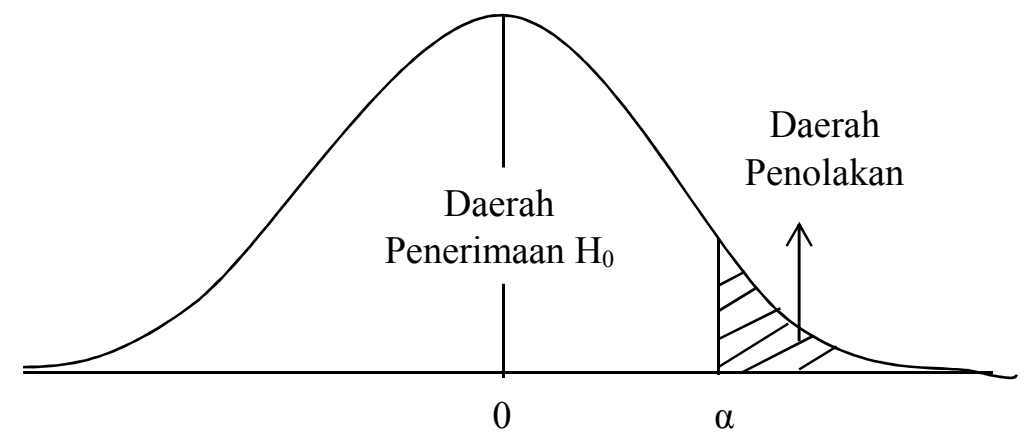

Tabel 10.

Uji Koefisien Determinasi

\begin{tabular}{ccccc}
\hline Model & $\mathrm{R}$ & $\mathrm{R}$ Square & $\begin{array}{c}\text { Adjusted R } \\
\text { Square }\end{array}$ & $\begin{array}{c}\text { Std. Error of the } \\
\text { Estimate }\end{array}$ \\
\hline 1 & $0,929^{\mathrm{a}}$ & 0,863 & 0,859 & 0,45876 \\
\hline
\end{tabular}

Sumber : Data sekunder diolah, 2018

Tabel 10. menjelaskan nilai koefisien determinasi sebesar 0,863. Hal ini menandakan sebesar 86,3\% variasi yield obligasi dapat dijelaskan oleh keempat variabel bebas yaitu kupon, maturitas, likuiditas dan suku bunga sedangkan sisanya sebesar $13,7 \%$ dijelaskan oleh variabel lain diluar model regresi.

\section{SIMPULAN}

Berdasarkan hasil data analisis yang telah dilakukan diperoleh bahwa pengaruh kupon, maturitas, likuiditas dan suku bunga terhadap yield obligasi diketahui bahwa sebesar 86,3 persen variasi yield obligasi dapat dijelaskan oleh 
model sedangkan sisanya sebesar 13,7 persen dijelaskan oleh variabel lain diluar model regresi. Hasil hipotesis menunjukkan kupon berpengaruh positif signifikan terhadap yield obligasi, maturitas berpengaruh positif signifikan terhadap yield obligasi, likuiditas berpengaruh negatif signifikan terhadap yield obligasi, dan suku bunga berpengaruh positif signifikan terhadap yield obligasi. Berikut adalah beberapa saran yang dapat diberikan.

Bagi perusahaan, diharapkan lebih cermat dalam mengamati perkembangan ekonomi baik mikro maupun makro antara lain kupon, maturitas, likuiditas dan suku bunga untuk menentukan nilai yield tanpa mengabaikan faktor-faktor lain seperti inflasi, nilai tukar, harga obligasi, dan sebagainya sebelum menerbitkan obligasi untuk menjaga kepercayaan investor dalam berinvestasi. Bagi investor diharapkan dapat membantu investor untuk lebih mengenali pengaruh kupon, maturitas, likuiditas dan suku bunga terhadap yield obligasi agar dapat menentukan keputusan investasi yang tepat dan dapat menghasilkan pengembalian yang optimal. Bagi peneliti selanjutnya diharapkan penelitian ini berguna sebagai referensi dengan menggunakan variabel yang relevan. Peneliti selanjutnya disarankan untuk menambah jumlah periode penelitian dan dapat menggunakan obyek yang berbeda seperti obligasi pemerintah maupun obligasi sub sektor tertentu.

\section{REFERENSI}

Andrew \& Wijaya, A. (2012). The Influence Of Coupon Bond And Bond Maturity To Bond Yield In Indonesia Stock Exchange. Miicema, 32-44.

Brigham, \& Houston. (2010). Dasar - Dasar Manajemen Keuangan. Jakarta: Salemba Empat.

Che-yahya, Norliza; Rusita, Abdul Rahim; Rasidah, Mohd-Rashid (2016). Determinants Of Corporate Bond Yield: The Case Of Malaysian Bond Market. International Journalof Business And Society, 17(2), 245-258.

Dhar, S. K. (2016). Determinants Of Corporate Bond'S Yields In Economy. Working Paper SSRN, 1-19.

Favero, C., Pagano, M., \& Thadden, E. (2007). How Does Liquidity Affect Government Bond Yields?. Working Paper, (181).

Handayani Dan Sri Artini. (2011). Pengaruh Faktor Ekonomi Makro, Keputusan Investasi Dan Keputusan Pendanaan Terhadap Yield Obligasi Korporasi Di Bursa Efek Indonesia. E-Journal Ekonomi Dan Bisnis Universitas Udayana, 2(4), 249-264.

Hartono, Jogiyanto. (2016). Teori Portofolio dan Analisis Investasi. Yogyakarta: BPFE.

Hsing, Y. (2015). Determinants Of The Government Bond Yield In Spain : A 
Loanable Funds Model. Int. J. Financial Stud, (3), 342-350. Https://doi.org/10.3390/ijfs3030342

Iman, F. (2015). Yield Obligasi Indonesia Turun. http://www.ibpa.co.id/News/ArsipBerita/tabid/126/EntryId/5694/YieldObligasi-Indonesia-Turun.aspx. (Diakses pada 30 Oktober 2018)

Indarsih, N. (2013). Nanik Indarsih; Pengaruh Tingkat Suku Bunga SBI, Rating, Likuiditas dan Maturitas Terhadap Yield to Maturity Obligasi. Jurnal Ilmu Manajemen, 1(1), 125-136.

Kurniasih \& Restika. (2015). The Influence Of Macroeconomic Indicators And Foreign Ownership On Government Bond Yields : A Case Of Indonesia. Mediterranean Journal Of Social Sciences, 6(5), 34-42. Https://doi.org/10.5901/mjss.2015.v6n5s5p34

Lin, Hai; Wang, J; Wud, Chunchi (2011). Liquidity Risk And Expected Corporate Bond Returns. Journal Of Financial Economics, 99(3), 628-650. Https://doi.org/10.1016/j.jfineco.2010.10.004

Muharam, H. (2013). Government Bond Yield Volatility And It's Determinants: The Case Of Indonesia Government Bond. Working Paper SSRN, 1-25.

Muthmainah, D. (2018). Penerbitan Baru Obligasi Korporasi Melejit 40 Persen. https://www.cnnindonesia.com/ekonomi/20171228144949-92-

265238/2017-penerbitan-baru-obligasi-korporasi-melejit-40-persen.

(Diakses pada 17 September 2018)

Pramana \& Nachrowi. (2016). The Effect Of Indonesian Macroeconomic Condition And International Interest Rate On Yield Of The Goverment Bond In Us Dollar. Journal Of Indonesian Applied Economics, 6(1), 44-65.

Purnamawati, I Gusti Ayu. (2013). Pengaruh Peringkat Obligasi, Tingkat Suku Bungasertifikat Bank Indonesia, Rasio Leverage, Ukuran Perusahaan Dan Umur Obligasi Pada Imbal Hasil Obligasi Korporasi Di Bursa Efek Indonesia. Jurnal Riset Akuntansi, 2(1), 28-45.

Putri, Ni Putu Kartika Eka; Astika Ida Bags Putra; Dewi, Ayu Arysta. (2017). Pengaruh Tingkat Bunga Pasar Dan Karakteristik Obligasi Pada Imbal Hasil Obligasi Yang Tergolong Investment Grade. E-Jurnal Akuntansi Universitas Udayana, 19(3), 1774-1802.

Putri, Eka Lestari Hafqi (2013). Pengaruh Risiko Likuiditas Perusahaan Terhadap Yield Spread Obligasi. Jurnal Ekonomi Dan Bisnis, (3), 294-306.

Saputra, Tyas Ardian (2014). Analisis Faktor-Faktor Yang Mempengaruhi Yield Obligasi Konvensional Di Indonesia ( Studi Kasus Pada Perusahaan Listed Di Bei ). Jurnal Studi Manajemen \& Organisasi, 11(1), 67-77. 
Sari, Ni Wayan Naluritha; Abundanti, Nyoman. (2015). Variabel-Variabel Yang Mempengaruhi Yield Obligasi Pada Perusahaan Yang Terdaftar Di Bursa Efek Indonesia. E-Jurnal Manajemen Unud, 4(11), 3796-3824.

Sihombing, P; Siregar, H; Manurng, A. H; Santosa, P.W. (2014). Determinants Of The Indonesia Government Yield Curve. International Journal Of Information Technology And Business Management, 2925(1), 22-37. Retrieved from www.jitbm.com

Susanti, Neneng ; Permana, Ruri. (2016). Pengaruh Peringkat, Likuiditas , Kupon Dan Maturitas Terhadap Yield Obligasi Pada Bursa Efek Indonesia ( Bei ) Periode 2013-2014. Jurnal Muara Ilmu Ekonomi Dan Bisnis, 1(1), 1-10.

Tandelilin, Eduardus. (2010). Analisis Investasi Dan Manajemen Portofolio Yogyakarta: BPFE.

Tandra, Hansen. (2018). Pengaruh Likuiditas, Ukuran Perusahaan, Dan Bi- Rate Terhadap Yield Obligasi Korporasi ( Studi Kasus Pada Sektor Industri Perbankan Yang Terdaftar Di Bursa Efek Indonesia Periode 2012-2016). Journal Manajemen, 7(1), 2-5.

Tjandrasa, Benny Budiawan. (2017). The Effect Of Consumer Expectation Index , Economic Condition Index And Crude Oil Price On Indonesian Government Bond Yield. Journal Of Economics, Business, And Accountancy Ventura, 20(1), 1-12. Https://doi.org/10.14414/jebav.v20i1.935

www.idx.co.id. (Diakses 20Agustus 2018)

Yuliani, Utami ; Juanda, B; Andanti, T(2016). Analysis The Influence Of Internal Factor And External Factor On Yield Bonds Government In. International Journal Of Science And Research, 5(8), 1090-1096. Https://doi.org/10.21275/art2016968 